\title{
PanCD44 Immunohistochemical Evaluation in Prostatectomies from Patients with Adenocarcinoma
}

\author{
Carlos Gustavo Hirth $\left(D,{ }^{1}\right.$ Adriele Machado dos Santos, ${ }^{2}$ \\ João Batista Gadelha de Cerqueira, ${ }^{3}$ Francisco Vagnaldo Fechine Jamacaru $\mathbb{D}^{\mathbb{D}}{ }^{2}$ \\ Maria do Perpétuo Socorro Saldanha da Cunha ${ }^{(D)}{ }^{4}$ and Conceição Aparecida Dornelas ${ }^{1}$ \\ ${ }^{1}$ Pathology Department, Federal University of Ceará, Fortaleza, CE, Brazil \\ ${ }^{2}$ Federal University of Ceará, Fortaleza, CE, Brazil \\ ${ }^{3}$ Urology Department, Federal University of Ceará, Fortaleza, CE, Brazil \\ ${ }^{4}$ Haroldo Juaçaba Hospital, Fortaleza, CE, Brazil
}

Correspondence should be addressed to Carlos Gustavo Hirth; carlos@hirth.com.br

Received 23 July 2017; Revised 3 December 2017; Accepted 15 January 2018; Published 26 February 2018

Academic Editor: Jeroen T. Buijs

Copyright (C) 2018 Carlos Gustavo Hirth et al. This is an open access article distributed under the Creative Commons Attribution License, which permits unrestricted use, distribution, and reproduction in any medium, provided the original work is properly cited.

Introduction. CD44 has been proposed as a prognostic marker and a stem cell marker but studies in patients with prostate cancer have yielded inconsistent results. Patients and Methods. Patients submitted to radical prostatectomy between 2008 and 2013 at a university hospital were followed with biannual serum PSA tests to determine the biochemical recurrence (BR). Archived paraffin blocks with neoplastic and nonneoplastic tissue were evaluated immunohistochemically for a panCD44 and MYC. Results. Sixtynine patients completed follow-up and were included. CD44 positivity was observed in inflammatory cells (42\%), nonneoplastic epithelium (39.7\%), and neoplastic tissue (12.3\%). In nonneoplastic tissues staining was observed in basal and luminal cells with the morphology of terminally differentiated cells. In neoplastic tissues, CD44 negativity was correlated with higher Gleason scores (Rho $=-0.204 ; p=0.042)$ and higher preoperative serum PSA levels when evaluated continuously $(p=0.029)$. CD44 expression was not associated with tumor stage $(p=0.668)$, surgical margin status $(p=0.471)$, or BR $(p=0.346)$, nor was there any association between CD44 and MYC expression in neoplastic tissue $(p=1.0)$. Conclusion. In the bulk of cells, the minority of cancer stem cells would not be detected by immunohistochemistry using panCD44. As a prognostic marker, its expression was weakly correlated with Gleason score and preoperative PSA level, but not with surgical margin status, tumor stage, or BR.

\section{Introduction}

The cell-surface glycoprotein CD44 plays a central role in cell-cell and cell-matrix adhesion [1-5]. Along with integrins and cadherins, CD44 promotes the fixation and maintenance of tissue integrity and participates in microenvironmental signal transduction [3], modulating cell growth, survival, differentiation, and mobility [3]. CD44 gene exons can be combined by alternative splicing to form several isoforms [6-8]. CD44s (standard), the smallest form of CD44, is universally expressed in vertebrates [3] and has been detected in lymphocytes, macrophages, granulocytes, fibroblasts, and epithelial cells [2]. There are at least 15 variants of CD44
(CD44v) with the same $\mathrm{N}$ - and C-terminal sequences but differing with regard to the central portion $[2,3,9]$. Its expression in prostate cancer is associated with reduced tumor aggressiveness [3, 10-12].

On the other hand, it has been hypothesized that stem cells in the basal epithelium are capable of self-renewal and differentiation into terminal cells $[13,14]$. Cancer-initiating cells constitute a specific transformed rare cell population with unchecked proliferation, which-unlike normal stem cells-may display genetic unstability and heterogeneity, favoring tumor formation and growth [9, 15-17]. Thus, approximately $0.1 \%$ of tumor cells would be stem cells [18]. Several markers have been used to identify and isolate stem 
cells [19], especially CD44 combined or not with other markers. CD44-positive cells can proliferate over long periods and give rise to other cell types with significant metastatic and tumorigenic potential $[20,21]$. In addition, CD44 expression has been associated with the presence neoplastic cells in the blood stream [22]. However, some authors believe the scope of CD44 expression in neoplasia is too wide to make it a useful stem cell marker [23].

MYC is one of the proteins regulated by CD44 [21]. MYCencoded proteins are transcription factors, the expression of which is correlated with cell proliferation, differentiation, and tumorigenesis $[24,25]$. This raises the possibility that the preference of MYC expression for basal prostate epithelium is evidence of the presence of stem cells [26].

The purpose of the present study was to evaluate the immunohistochemical expression of panCD44 in neoplastic and nonneoplastic prostate epithelium, determining its association with tumor aggressiveness (preoperative PSA level, Gleason score, tumor stage, surgical margin status, and biochemical recurrence) and C-MYC expression.

\section{Patients and Methods}

2.1. Study Population, Ethical Considerations, and Prognostic Factors. The sample consisted of all patients with localized prostate cancer (clinical stages T1 and T2) [27] submitted to radical prostatectomy between January 2008 and December 2013 at a referral hospital (Hospital Universitário Walter Cantídio/UFC) in Northeastern Brazil (Fortaleza, Ceará). The patients were followed clinically with biannual serum PSA tests between January 2008 and June 2016. Patients missing follow-up visits were excluded from the sample. The study protocol was approved by the institutional ethics committee and all patients gave their informed written consent. Biochemical recurrence (BR) was defined as a sustained $(\geq 2$ measurements) PSA level of $\geq 0.2 \mathrm{ng} / \mathrm{mL}$ after reaching PSA nadir $[28,29]$. The data were entered in a protocol designed for the study, according to the time elapsed between surgery and $\mathrm{BR}$ or censoring. In the absence of $\mathrm{BR}$, the patients were censored on the day of the last PSA measurement. Information on preoperative serum PSA levels was retrieved from the medical records. The histology slides were reviewed by a pathologist blinded to the clinical data. Modified Gleason scores were assigned following $2016 \mathrm{WHO}$ guidelines [30]. The pathological stage was determined according to the 2010 AJCC Cancer Staging Manual [27], considering the criteria for extraprostatic extension and seminal vesicle involvement in the 2011 guidelines of the International Society of Urological Pathology (ISUP) [31, 32]. Neoplastic cells in contact with the india ink used in the processing of the specimen were considered evidence of compromised surgical margins [33].

2.2. Immunohistochemistry for CD44 and C-MYC. The immunohistochemical evaluation used archived paraffin blocks. Fragments were selected which contained adenocarcinoma, benign gland tissue, and specimens with highly variable Gleason scores (the higher, the better). Three-micrometer sections were placed on silanized slides according to standard laboratory procedures [34], followed by incubation at $60^{\circ} \mathrm{C}$ for one hour. Diaphonization, rehydration, and heat-induced epitope retrieval were performed with a Dako PT Link ${ }^{\mathrm{TM}}$ pretreatment module and Tris/EDTA buffer at $\mathrm{pH} 9.0$ (Dako). Automated reactions were performed with an Auto Stainer $\left(\mathrm{Dako}^{\mathrm{TM}}\right)$. CD44 reactions were performed with the clone SFF-2 (Santa Cruz, sc-65405, 2015, dilution $1 / 100$, incubation $30 \mathrm{~min}$ ). The reactions were evaluated semiquantitatively under an optical microscope (Nikon Eclipse E200). The samples were considered positive when the membrane stained with a total score of $>3$, as described elsewhere [35]: the proportion of positive cells in relation to the total sample was classified as $0(0-5 \%), 1$ (6-25\%), $2(26-75 \%)$, or $3(76-100 \%)$, while intensity was classified as 0 (absent), 1 (weak, positivity observed at 400x), 2 (intermediate, positivity observed at $100 \mathrm{x}$ ), or 3 (strong, positivity observed at 40x). MYC reactions were performed with the clone Y69 (Abcam, ab32072, 2015, dilution 1/100, incubation $60 \mathrm{~min}$ ). The results were plotted as positive or negative for nonneoplastic epithelium, blood vessels, and neoplastic tissue [36].

2.3. Statistical Analysis. The statistical analysis was made with the software IBM SPSS v.22. The normality of the data was verified with the Shapiro-Wilk test, while the Mann-Whitney test was used to verify potential associations between CD44 expression and serum PSA levels. The frequency analysis of the categorical variables was done with Fisher's exact test and odds ratios (95\% confidence interval). The Spearman test was employed to verify correlations between CD44s expression and Gleason patterns. Kaplan-Meier curves were generated and compared with the log rank test. Univariate Cox regression was used to detect associations between BR and CD44s expression. The level of two-tailed statistical significance was set at $5 \%(p \leq 0.05)$.

\section{Results}

3.1. Patients. During the study period, 74 patients were submitted to radical prostatectomy. The criteria for clinical follow-up were met by 69 subjects (93.2\%), with a mean follow-up time of 41 months (range: 2-89), during which $20(29 \%)$ were diagnosed with BR. In four paraffin blocks, the neoplasia was exhausted (no immunohistochemical representation). The same occurred with one sample of benign epithelium.

3.2. CD44 and MYC. The membrane and cytoplasm of inflammatory cells stained positive for CD44 (intensely and/or extensively) in $42 \%$ of the samples (Figure 1). As for normal epithelium (positivity: 39.7\%), staining was circumferential in basal cells and basolateral in luminal cells (the latter displaying the morphology of terminally differentiated cells) (Figure 2). In neoplastic cells (positivity: $12.3 \%)$, staining was circumferential, basolateral, or focal (Figure 3).

The immunohistochemical findings for CD44 are summarized in Table 1. CD44 expression was statistically similar 


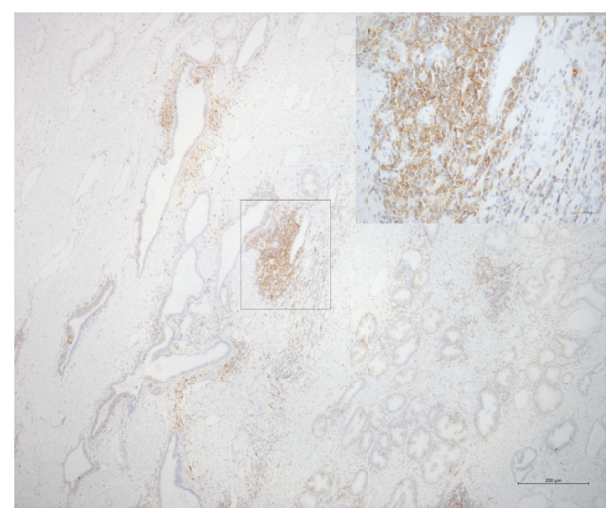

FIGURE 1: Photomicrograph of immunohistochemical staining for CD44 in stromal inflammatory cells. Staining was observed in the membrane and cytoplasm (magnification: 50x; detail: 400x).

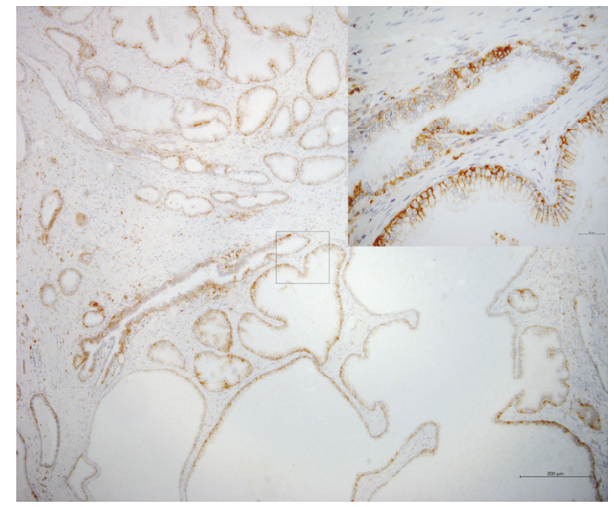

FIGURE 2: Photomicrograph of immunohistochemical staining for CD44 in nonneoplastic epithelium. Staining was basolateral in luminal cells and circumferential in basal cells. The intensity was grade 3 in over $75 \%$ of the cells (magnification: 100x; detail 400x).

in inflammatory cells and benign epithelium $(p=0.862)$, but significantly weaker in neoplasia $(p \leq 0.001)$.

CD44 positivity in neoplastic cells was associated with lower preoperative PSA levels. Thus, the median level was $5.43 \mathrm{ng} / \mathrm{mL}$ (range: $4.16-16.35$ ) in positive cases and $8.42 \mathrm{ng} / \mathrm{mL}$ (range: $3.06-94.3$ ) in negative cases $(p=0.029$ ). The CD44 staining score was inversely but weakly correlated with Gleason pattern (Rho $=-0.204 ; p=0.042$ ), but the association was nonsignificant when the PSA values were categorized and the Gleason scores were stratified (Table 2).

The presence or absence of immunoexpression for CD44 was not associated with tumor stage, surgical margins, or BR (Table 2; Figure 4). The univariate Cox regression yielded a hazard ratio of 1.100 (95\% IC: $0.446-2.710 ; p=0.836$ ) for the relation between $\mathrm{CD} 44$ expression and $\mathrm{BR}$.

Nuclear staining for MYC was observed in rare endothelial cells ( $40.6 \%$ of cases), nonneoplastic basal epithelial cells (25\%), and neoplastic cells (27.3\%). MYC expression and CD44 expression were significantly associated in nonneoplastic epithelium, but not in neoplastic tissue.

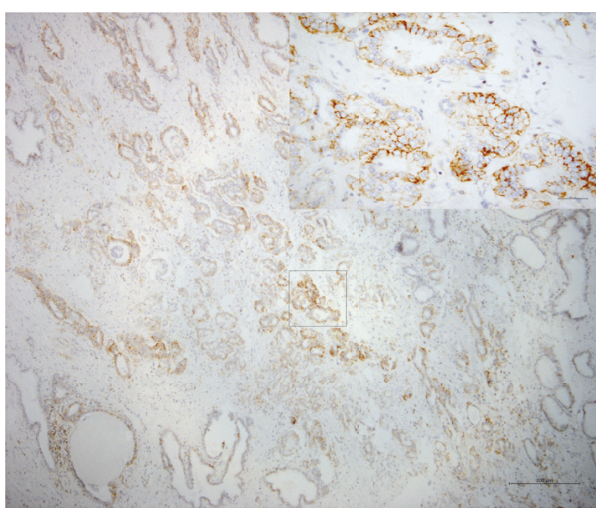

FIGURE 3: Photomicrograph of immunohistochemical staining for CD44 in neoplastic cells. Staining was basolateral. The intensity was grade 3 in over $75 \%$ of the cells (magnification: 50x; detail 400x).

TABle 1: Summary of immunohistochemical findings for CD44, plotted according to negative scores (0-3) and positive scores (4-6).

\begin{tabular}{lccc}
\hline & $\begin{array}{c}\text { Inflammatory } \\
\text { cells }\end{array}$ & $\begin{array}{c}\text { Nonneoplastic } \\
\text { cells }\end{array}$ & $\begin{array}{c}\text { Neoplastic } \\
\text { cells }\end{array}$ \\
\hline Total & 69 & 68 & 65 \\
Negative & $40(58.0 \%)$ & $41(60.3 \%)$ & $57(87.7 \%)$ \\
Positive & $29(42.0 \%)$ & $27(39.7 \%)$ & $8(12.3 \%)$ \\
\hline
\end{tabular}

\section{Discussion}

The ability of CD44 expression in biopsies and transurethral resections to predict tumor aggressiveness in prostatectomies had been evaluated [37, 38], as had the association of biopsies and transurethral resections with anatomopathological factors and tumor progression [39-41]. Some authors have focused on primary tumors and metastases [10, 42-45]. In this study, we focused on prostatectomies.

The detection of CD44 on immunohistochemistry may be approached in many different ways (Table S1). CD44 goes under a variety of names, data may be plotted in different forms, and different clones may be used. Over time, PSA detection techniques have become ultrasensitive, staging criteria have been revised, Gleason scores have been modified, and different cut-off values have been used to define BR. This makes studies highly heterogeneous and difficult to compare, compromising attempts at meta-analysis.

Cut-off values for CD44 generally indicate "superexpression" or "intense expression," as in Aaltomaa et al. (2001) [41], in which positivity was defined as staining of $80 \%$ cells, below which associations were considered "weak."

In our study, preoperative serum PSA levels were lower in CD44-positive patients than in CD44-negative patients, but the association was nonsignificant when PSA levels were stratified using $10 \mathrm{ng} / \mathrm{mL}$ as cut-off. An association between CD44 status and PSA level was also reported by Aaltoma et al. (2002) [46], but not by Kallakury et al. (1998) [47] and Tei et al. (2014) [35] who failed to detect an association when PSA levels were stratified $(10 \mathrm{ng} / \mathrm{mL})$. 
TABLE 2: Staining for CD44 in neoplastic cells stratified into negative (0-3) and positive (4-6).

\begin{tabular}{|c|c|c|c|c|}
\hline Factor & CD44-negative & CD44-positive & $p$ value & OR $(95 \%$ CI $)$ \\
\hline \multicolumn{5}{|l|}{$P S A$} \\
\hline$<10$ & $35(61.4 \%)^{*}$ & $7(87.5 \%)$ & \multirow{2}{*}{0.242} & 0.227 \\
\hline$\geq 10$ & $22(38.6 \%)$ & $1(12.5 \%)$ & & $(0.026-1.975)$ \\
\hline \multicolumn{5}{|l|}{ Gleason score } \\
\hline$\leq 6$ & $31(54.4 \%)$ & $6(75.0 \%)$ & \multirow{2}{*}{0.449} & 0.397 \\
\hline$\geq 7$ & $26(45.6 \%)$ & $2(25.0 \%)$ & & $(0.074-2.139)$ \\
\hline \multicolumn{5}{|l|}{ Tumor stage } \\
\hline pT2 & $42(73.7 \%)$ & $7(87.5 \%)$ & \multirow{2}{*}{0.668} & 0.400 \\
\hline pT3 & $15(26.3 \%)$ & $1(2.5 \%)$ & & $(0.045-3.527)$ \\
\hline \multicolumn{5}{|l|}{ Surgical margins } \\
\hline Free & $34(59.6 \%)$ & $6(75.0 \%)$ & \multirow{2}{*}{0.471} & 0.493 \\
\hline Compromised & $23(40.4 \%)$ & $2(25.0 \%)$ & & $(0.091-2.659)$ \\
\hline \multicolumn{5}{|l|}{$B R$} \\
\hline Absent & $22(68.7 \%)$ & $20(69.0 \%)$ & \multirow{2}{*}{1.0} & 0.990 \\
\hline Present & $10(32.3 \%)$ & $9(31.0 \%)$ & & $(0.334-2.930)$ \\
\hline
\end{tabular}

PSA = prostatic specific antigen; $\mathrm{BR}=$ biochemical recurrence; OR $(95 \% \mathrm{CI})=$ odds ratio and $95 \%$ confidence interval; ${ }^{*}$ columns percentage. The level of significance was evaluated with Fisher's exact test.

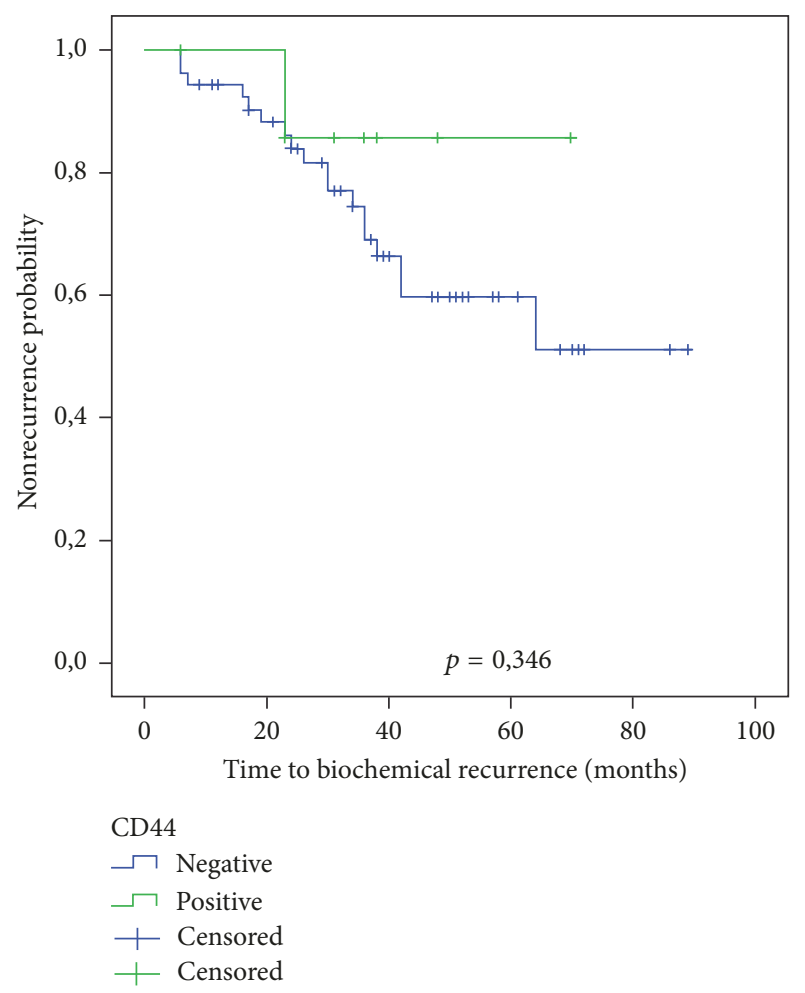

FIGURE 4: Kaplan-Meier curve showing the probability of biochemical recurrence according to CD44 positivity in neoplastic cells. The level of significance was evaluated with the log rank test.

CD44 positivity and Gleason score were correlated, showing a decline in CD44 expression from Gleason pattern 1 to Gleason pattern 5 [11], in our study with a weak Spearman correlation coefficient $(-0.204)$ but a significant $p$ value. However, when the Gleason scores were summed up and stratified, the association was nonsignificant. De Marzo et al. [10] tested a number of hypotheses using contingency tables to compare Gleason scores with CD44 expression in normal epithelium, intraepithelial neoplasia, and carcinoma and observed an inverse correlation between the patterns, especially Gleason 4 and 5. CD44 expression is no doubt weaker in neoplastic tissue than in healthy tissue and weaker in poorly differentiated neoplasia than in welldifferentiated neoplasia, resembling the behavior of other adhesions molecules such as E-cadherin [48].

The lack of association between CD44 expression and tumor stage observed in this study matches the findings of several authors [22, 35, 46, 47], but not those of Lazari et al. (2013) [48] and Noordzij et al. (1997) [11]. The former focused on the loss of expression of cell adhesion molecules. The latter stratified CD44 levels and tumor stage into four groups and submitted the findings to the chi-squared test, but in one of the cells the expected value was under 5, compromising the statistical power of the test. In 2000, Vis and coworkers reviewed their findings from 1997 and republished the Spearman correlation coefficient -0.49 ( $p=$ 0.001 ) [49] as evidence of an association between CD44 and tumor stage.

Matching the results of other authors [35, 46], in our study no association between CD44 staining and surgical margin status was observed.

Finally, CD44 was not associated with BR. Only one of the reviewed studies found an association with BR in all analyses (Noordzij et al., 1997) [11]. In the remainder, no such association was found in the univariate analysis or, if found, was nonsignificant in the multivariate analysis $[22,29,35,46$, 47] (Table S2). Noordzij et al. (1997) [11] and Vis et al. (2000) [49] also found CD44 expression to be related to clinical progression and specific mortality.

A large proportion of neoplastic and nonneoplastic cells express CD44, as shown in the literature in general, with 
some authors reporting positivity rates approaching $100 \%$ [23], a rate far above that expected for stem cells. In addition, CD44 expression and MYC expression were not associated in neoplastic tissues. Nevertheless, CD44 variants are believed to be better markers for stem cells, in association or not with other markers such as CD133, CD24, CD40, and $\alpha 2 \beta 1$ integrin. While the number of commercially available antibodies against CD $44 \mathrm{v}$ is still limited, ongoing research is likely to expand the range of options in the near future [50].

Our study was limited by the small sample size, by the use of archived specimens, and by the short time of follow-up. However, our results are supported by other studies showing high rates of CD44 positivity in prostate tissues, contrary to what would be expected for a stem cells marker. Our method of CD44 analysis was similar to that of Tei et al. (2014) [35], as were the results, despite demographic differences between the two samples (Brazil and Japan). Our study does not pretend to be conclusive regarding the role of CD44 in the prognosis of prostatectomized patients, or the potential of CD44 as a stem cell marker. To clarify the issue, studies on much larger samples would be useful or, considering the wide scope of studies conducted so far, a retrograde review of the data and a standardization of the plotting procedures.

\section{Conclusion}

CD44 expression was stronger in inflammatory and nonneoplastic cells than in tumor cells. Within the latter, expression was stronger in well-differentiated than poorly differentiated tumors. The loss of CD44 expression on immunohistochemistry was weakly associated with greater tumor aggressiveness (lower preoperative PSA levels and Gleason scores), but no correlation with biochemical recurrence was observed. The wide range of panCD44 expression in prostate tissues would not detect the minute minority of cancer stem cells by immunohistochemistry.

\section{Disclosure}

This work is part of the dissertation [51] carried out on Departamento de Patologia e Medicina Legal, Universidade Federal do Ceará, Ceará, Brazil.

\section{Conflicts of Interest}

The authors declare that there are no conflicts of interest regarding the publication of this paper.

\section{Acknowledgments}

This study was conducted at Federal University of Ceará, Pathology and Urology Departments, Monsenhor Furtado St., Rodolfo Teófilo, Fortaleza, CE, Brazil.

\section{Supplementary Materials}

Supplementary material contains revised articles on CD44 as a prognostic factor in prostatectomies from patients with adenocarcinoma. Table S1: immunohistochemical evaluations of CD44 expression in prostatectomies. Table S2: studies on biochemical recurrence of prostate cancer evaluating CD44 expression in radical prostatectomy. (Supplementary Materials)

\section{References}

[1] J. Lesley, R. Hyman, and P. W. Kincade, "CD44 and its interaction with extracellular matrix," Advances in Immunology, vol. 54, pp. 271-335, 1993.

[2] L. Y. W. Bourguignon, N. Iida, C. F. Welsh, D. Zhu, A. Krongrad, and D. Pasquale, "Involvement of CD44 and its variant isoforms in membrane-cytoskeleton interaction, cell adhesion and tumor metastasis," Journal of Neuro-Oncology, vol. 26, no. 3, pp. 201208, 1995.

[3] H. Ponta, L. Sherman, and P. A. Herrlich, "CD44: from adhesion molecules to signalling regulators," Nature Reviews Molecular Cell Biology, vol. 4, no. 1, pp. 33-45, 2003.

[4] D. Zhu and L. Y. W. Bourguignon, "The ankyrin-binding domain of CD44s is involved in regulating hyaluronic acidmediated functions and prostate tumor cell transformation," Cell Motility and the Cytoskeleton, vol. 39, no. 3, pp. 209-222, 1998.

[5] W. M. Gallatin, I. L. Weissman, and E. C. Butcher, "A cell-surface molecule involved in organ-specific homing of lymphocytes," Nature, vol. 304, no. 5921, pp. 30-34, 1983.

[6] D. Naor, S. B. Wallach-Dayan, M. A. Zahalka, and R. V. Sionov, "Involvement of CD44, a molecule with a thousand faces, in cancer dissemination," Seminars in Cancer Biology, vol. 18, no. 4, pp. 260-267, 2008.

[7] G. R. Screaton, M. V. Bell, D. G. Jackson, F. B. Cornelis, U. Gerth, and J. I. Bell, "Genomic structure of DNA encoding the lymphocyte homing receptor CD44 reveals at least 12 alternatively spliced exons," Proceedings of the National Acadamy of Sciences of the United States of America, vol. 89, no. 24, pp. 12160-12164, 1992.

[8] L. A. Goldstein, D. F. H. Zhou, L. J. Picker et al., "A human lymphocyte homing receptor, the Hermes antigen, is related to cartilage proteoglycan core and link proteins," Cell, vol. 56, no. 6, pp. 1063-1072, 1989.

[9] M. Zöller, "CD44: can a cancer-initiating cell profit from an abundantly expressed molecule?" Nature Reviews Cancer, vol. 11, no. 4, pp. 254-267, 2011.

[10] A. M. De Marzo, C. Bradshaw, J. Sauvageot, J. I. Epstein, and G. J. Miller, "CD44 and CD44v6 downregulation in clinical prostatic carcinoma: Relation to Gleason grade and cytoarchitecture," The Prostate, vol. 34, no. 3, pp. 162-168, 1998.

[11] M. A. Noordzij, G.-J. Van Steenbrugge, N. S. Verkaik, F. H. Schröder, and T. H. Van Der Kwast, "The prognostic value of CD44 isoforms in prostate cancer patients treated by radical prostatectomy," Clinical Cancer Research, vol. 3, no. 5, pp. 805815, 1997.

[12] A. C. Gao, W. Lou, J.-T. Dong, and J. T. Isaacs, "CD44 is a metastasis suppressor gene for prostatic cancer located on human chromosome 11p13," Cancer Research, vol. 57, no. 5, pp. 846-849, 1997.

[13] C. S. Foster, A. Dodson, V. Karavana, P. H. Smith, and Y. Ke, "Prostatic stem cells," The Journal of Pathology, vol. 197, no. 4, pp. 551-565, 2002. 
[14] A. T. Collins, F. K. Habib, N. J. Maitland, and D. E. Neal, "Identification and isolation of human prostate epithelial stem cells based on alpha(2)beta(1)-integrin expression," Journal of Cell Science, vol. 114, part 21, pp. 3865-3872, 2001.

[15] N. A. Lobo, Y. Shimono, D. Qian, and M. F. Clarke, “The biology of cancer stem cells," Annual Review of Cell and Developmental Biology, vol. 23, no. 1, pp. 675-699, 2007.

[16] R. P. Hill and R. Perris, "Destemming' cancer stem cells," Journal of the National Cancer Institute, vol. 99, no. 19, pp. 14351440, 2007.

[17] T. Reya, S. J. Morrison, M. F. Clarke, and I. L. Weissman, "Stem cells, cancer, and cancer stem cells," Nature, vol. 414, no. 6859, pp. 105-111, 2001.

[18] A. T. Collins, P. A. Berry, C. Hyde, M. J. Stower, and N. J. Maitland, "Prospective identification of tumorigenic prostate cancer stem cells," Cancer Research, vol. 65, no. 23, pp. 1094610951, 2005.

[19] E. A. Castellón, R. Valenzuela, J. Lillo et al., "Molecular signature of cancer stem cells isolated from prostate carcinoma and expression of stem markers in different Gleason grades and metastasis," Biological Research, vol. 45, no. 3, pp. 297-305, 2012.

[20] L. Patrawala, T. Calhoun, R. Schneider-Broussard et al., "Highly purified $\mathrm{CD} 44^{+}$prostate cancer cells from xenograft human tumors are enriched in tumorigenic and metastatic progenitor cells," Oncogene, vol. 25, no. 12, pp. 1696-1708, 2006.

[21] Y.-J. Su, H.-M. Lai, Y.-W. Chang, G.-Y. Chen, and J.-L. Lee, "Direct reprogramming of stem cell properties in colon cancer cells by CD44," EMBO Journal, vol. 30, no. 15, pp. 3186-3199, 2011.

[22] V. Paradis, P. Eschwège, S. Loric et al., "De novo expression of CD44 in prostate carcinoma is correlated with systemic dissemination of prostate cancer," Journal of Clinical Pathology, vol. 51, no. 11, pp. 798-802, 1998.

[23] A. V. Ugolkov, L. J. Eisengart, C. Luan, and X. J. Yang, "Expression analysis of putative stem cell markers in human benign and malignant prostate," The Prostate, vol. 71, no. 1, pp. 18-25, 2011.

[24] M. D. Cole, “The myc oncogene: its role in transformation and differentiation.", Annual Review of Genetics, vol. 20, pp. 361-384, 1986.

[25] C. Grandori, S. M. Cowley, L. P. James, and R. N. Eisenman, "The Myc/Max/Mad network and the transcriptional control of cell behavior," Annual Review of Cell and Developmental Biology, vol. 16, no. 1, pp. 653-699, 2000.

[26] B. Gurel, T. Iwata, C. M. Koh et al., "Nuclear MYC protein overexpression is an early alteration in human prostate carcinogenesis," Modern Pathology, vol. 21, no. 9, pp. 1156-1167, 2008.

[27] AJCC Cancer Staging Manual, New York, NY, USA, 7th edition edition, 2010.

[28] M. S. Cookson, G. Aus, A. L. Burnett et al., "Variation in the definition of biochemical recurrence in patients treated for localized prostate cancer: the American urological association prostate guidelines for localized prostate cancer update panel report and recommendations for a standard in the reporting of surgical outcomes," The Journal of Urology, vol. 177, no. 2, pp. 540-545, 2007.

[29] S. F. Brewster, J. D. Oxley, M. Trivella, C. D. Abbott, and D. A. Gillatt, "Preoperative p53, bcl-2, CD44 and E-cadherin immunohistochemistry as predictors of biochemical relapse after radical prostatectomy," The Journal of Urology, vol. 161, no. 4, pp. 1238-1243, 1999.
[30] P. A. Humprey, M. B. Amin, D. M. Berney, A. Billis et al., "Adenocarcinoma Acinar," in WHO Classification of Tumours of the Urinary System and Male Genital Organs, IARC, Lyon, France, 4th edition edition, 2016.

[31] D. M. Berney, T. M. Wheeler, D. J. Grignon et al., "International society of urological pathology (ISUP) consensus conference on handling and staging of radical prostatectomy specimens. working group 4: Seminal vesicles and lymph nodes," Modern Pathology, vol. 24, no. 1, pp. 39-47, 2011.

[32] C. Magi-Galluzzi, A. J. Evans, B. Delahunt et al., "International society of urological pathology (ISUP) consensus conference on handling and staging of radical prostatectomy specimens. working group 3: Extraprostatic extension, lymphovascular invasion and locally advanced disease," Modern Pathology, vol. 24, no. 1, pp. 26-38, 2011.

[33] P. H. Tan, L. Cheng, J. R. Srigley et al., "International society of urological pathology (ISUP) consensus conference on handling and staging of radical prostatectomy specimens. Working group 5: Surgical margins," Modern Pathology, vol. 24, no. 1, pp. 48-57, 2011.

[34] G. S. Palapattu, C. Wu, C. R. Silvers et al., "Selective expression of CD44, a putative prostate cancer stem cell marker, in neuroendocrine tumor cells of human prostate cancer," The Prostate, vol. 69, no. 7, pp. 787-798, 2009.

[35] H. Tei, H. Miyake, K.-I. Harada, and M. Fujisawa, "Expression profile of CD44s, CD44v6, and CD44v10 in localized prostate cancer: Effect on prognostic outcomes following radical prostatectomy," Urologic Oncology: Seminars and Original Investigations, vol. 32, no. 5, pp. 694-700, 2014.

[36] G. Fromont, J. Godet, A. Peyret et al., " 8 q24 amplification is associated with Myc expression and prostate cancer progression and is an independent predictor of recurrence after radical prostatectomy," Human Pathology, vol. 44, no. 8, pp. 1617-1623, 2013.

[37] K. Korski, A. Malicka-Durczak, and J. Bręborowicz, "Expression of stem cell marker CD44 in prostate cancer biopsies predicts cancer grade in radical prostatectomy specimens," Polish Journal of Pathology, vol. 65, no. 4, pp. 291-295, 2014.

[38] S. Gunia, M. May, S. Koch, M. Dietel, and A. Erbersdobler, "Expression of CD44s in incidental prostate cancer is more strongly associated with gleason scores on subsequent radical prostatectomies than conventional prognostic parameters," Pathobiology, vol. 76, no. 6, pp. 286-292, 2009.

[39] S. Takahashi, N. Kimoto, S.-I. Orita, L. Cui, M. Sakakibara, and T. Shirai, "Relationship between CD44 expression and differentiation of human prostate adenocarcinomas," Cancer Letters, vol. 129, no. 1, pp. 97-102, 1998.

[40] A. N. Vis, B. W. G. van Rhijn, M. A. Noordzij, F. H. Schröder, and T. H. van der Kwast, "Value of tissue markers p27(kip1), MIB-1, and CD44s for the pre-operative prediction of tumour features in screen-detected prostate cancer," The Journal of Pathology, vol. 197, no. 2, pp. 148-154, 2002.

[41] S. Aaltomaa, P. Lipponen, M. Ala-Opas, and V.-M. Kosma, "Expression and prognostic value of CD44 standard and variant v3 and v6 isoforms in prostate cancer," European Urology, vol. 39, no. 2, pp. 138-144, 2001.

[42] B. V. S. Kallakury, F. Yang, J. Figge et al., "Decreased levels of CD44 protein and mRNA in prostate carcinoma: correlation with tumor grade and ploidy," Cancer, vol. 78, no. 7, pp. 1461$1469,1996$.

[43] M. Nagabhushan, T. G. Pretlow, Y.-J. Guo, S. B. Amini, T. P. Pretlow, and M.-S. Sy, "Altered expression of CD44 in 
human prostate cancer during progression," American Journal of Clinical Pathology, vol. 106, no. 5, pp. 647-651, 1996.

[44] C. L. Eaton, M. Colombel, G. van der Pluijm et al., "Evaluation of the frequency of putative prostate cancer stem cells in primary and metastatic prostate cancer," The Prostate, vol. 70, no. 8, pp. 875-882, 2010.

[45] M. A. Noordzu, G. J. Van Steenbrugge, F. H. Schröder, and T. H. Van Der Kwast, "Decreased expression of cd44 in metastatic prostate cancer," International Journal of Cancer, vol. 84, no. 5, pp. 478-483, 1999.

[46] S. Aaltomaa, P. Lipponen, R. Tammi et al., "Strong stromal hyaluronan expression is associated with PSA recurrence in local prostate cancer," Urologia Internationalis, vol. 69, no. 4, pp. 266-272, 2002.

[47] B. V. Kallakury, C. E. Sheehan, R. A. Ambros et al., "Correlation of p34cdc2 cyclin-dependent kinase overexpression, CD44s downregulation, and HER-2/neu oncogene amplification with recurrence in prostatic adenocarcinomas," Journal of Clinical Oncology: Official Journal of the American Society of Clinical Oncology, vol. 16, no. 4, pp. 1302-1309, 1998.

[48] P. Lazari, H. Poulias, H. Gakiopoulou, G.-H. Thomopoulou, C. Barbatis, and A. C. Lazaris, "Differential immunohistochemical expression of CD44s, E-cadherin and $\beta$-catenin among hyperplastic and neoplastic lesions of the prostate gland," Urologia Internationalis, vol. 90, no. 1, pp. 109-116, 2013.

[49] A. N. Vis, M. A. Noordzij, K. Fitoz, M. F. Wildhagen, F. H. Schröder, and T. H. Van Der Kwast, "Prognostic value of cell cycle proteins p27(kipl) and MIB-1, and the cell adhesion protein $\mathrm{CD} 44 \mathrm{~s}$ in surgically treated patients with prostate cancer," The Journal of Urology, vol. 164, no. 6, pp. 2156-2161, 2000.

[50] Y. Yan, X. Zuo, and D. Wei, "Concise review: Emerging role of CD44 in cancer stem cells: A promising biomarker and therapeutic target," Stem Cells Translational Medicine, vol. 4, no. 9, pp. 1033-1043, 2015.

[51] C. G. Hirth and C. A. Dornelas, "Valor prognóstico de marcadores de diferenciação neuroendócrina e de células-tronco em pacientes submetidos a prostatectomia radical por câncer de próstata localizado. 134 f. Dissertation - Faculdade de Medicina, Universidade Federal do Ceará, Fortaleza," 2016, http://www .repositorio.ufc.br/handle/riufc/21568. 


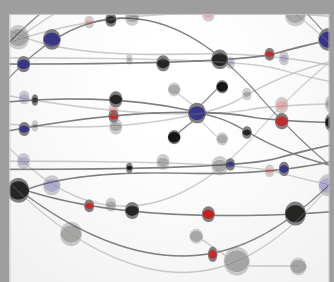

The Scientific World Journal
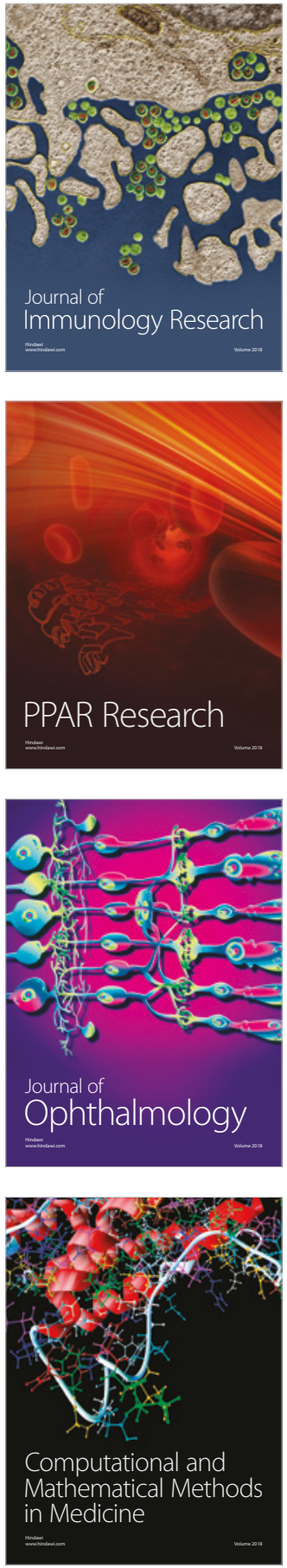

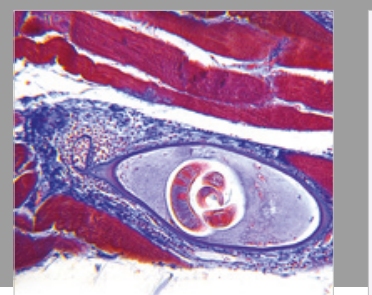

Gastroenterology Research and Practice

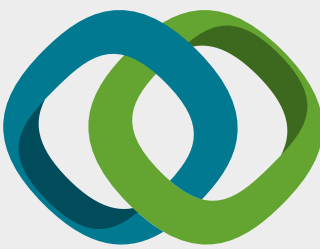

\section{Hindawi}

Submit your manuscripts at

www.hindawi.com
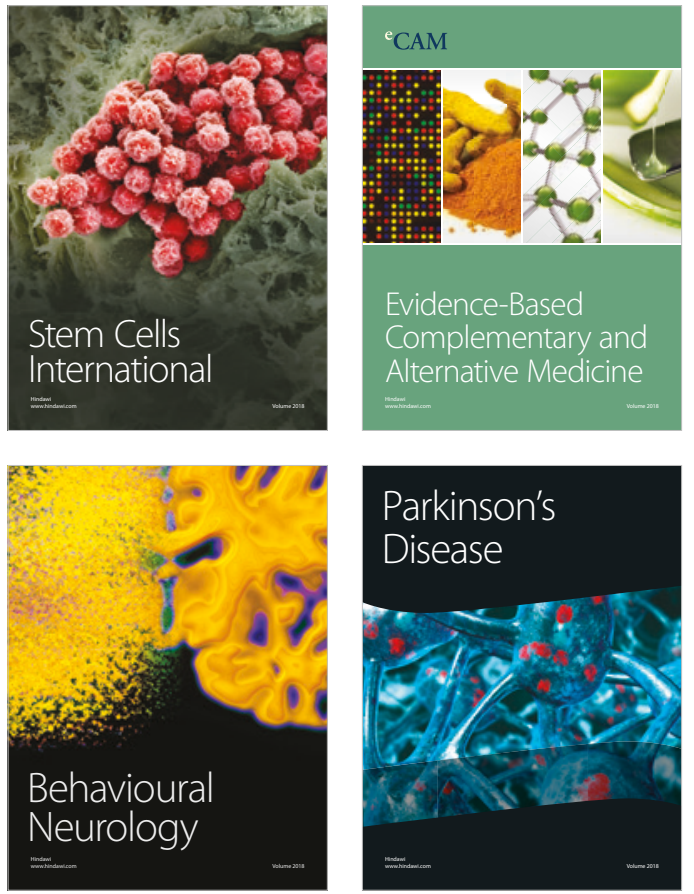

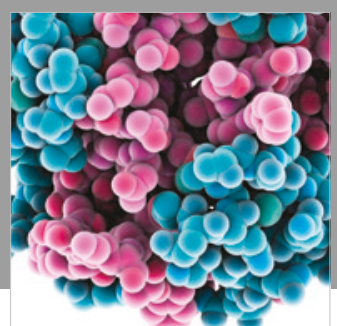

ournal of

Diabetes Research

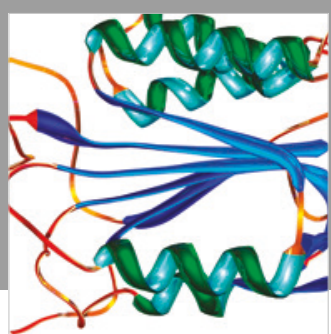

Disease Markers
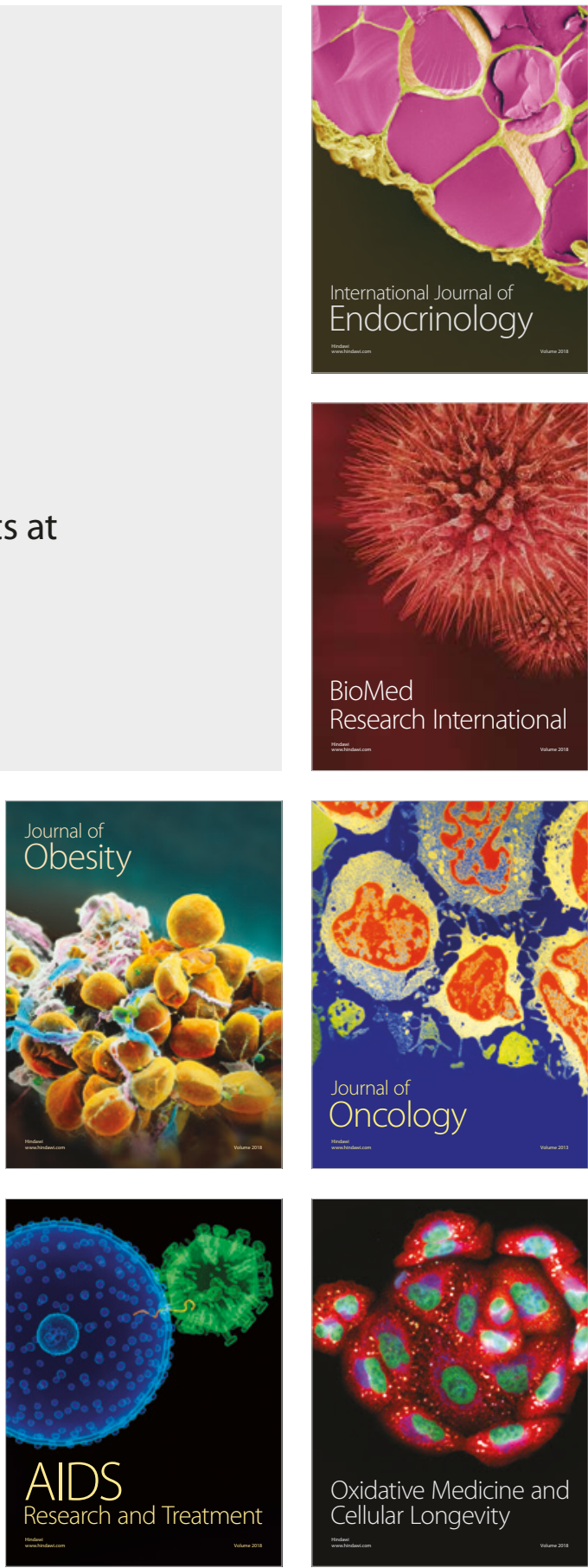